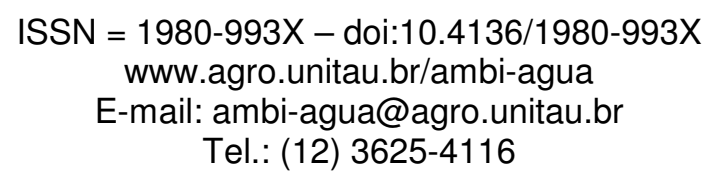

\title{
Application of a 2D shallow water model to analyze the flow and the use of groins to protect an area of the Amazon river estuary (doi:10.4136/ambi-agua.82)
}

\author{
Claudio José Cavalcante Blanco ${ }^{1}$; André Luiz Amarante Mesquita ${ }^{2}$; Manoel José dos \\ Santos Sena ${ }^{3}$; Yves Secretan ${ }^{4}$ \\ ${ }^{1}$ School of Sanitary Environmental Engineering, Federal University of Pará \\ E-mail: blanco@ufpa.br \\ ${ }^{2}$ School of Mechanical Engineering, Federal University of Pará \\ E-mail: andream@ufpa.br \\ ${ }^{3}$ IESAM - Instituto de Estudos Superiores da Amazônia \\ E-mail:mjssena@prof.iesam-pa.edu.br \\ ${ }^{4}$ INRS-ETE, Québec, QC G1K 9A9, Canada \\ E-mail: yves.secretan@ete.inrs.ca
}

\begin{abstract}
The waterfront of Belém, the capital of Pará State, Brazil, has undergone a beautification process whereby a hydraulic embankment is being executed at a section located at the confluence of the Guamá River and the Guajará Bay. A two-way avenue and a leisure and tourist complex will be built on this filled area. Protection of the construction site may be required in order to minimize loss of material during the build up operation and it could serve to maintain the tourist complex as well. Other important point is the impact analysis of the construction on the global flow at the confluence of the Guamá River and the Guajará Bay. Thus, a two-dimensional hydrodynamic finite elements model is used to simulate the velocities in the region for three configurations, namely: the first with the natural configuration of the area; the second where the work area is being protected by one groin; and the third one with two groins. The flow simulation for flood tide or ebb tide showed that for flood tide the velocities are higher than those in ebb tide. The simulated velocities with the presence of groins are slower than those simulated with the natural configuration model. Thus, it shows the efficacy of the groins to slow down the currents' velocities. In addition, the groins could protect the section of the revitalized Belém shore. In a general way, the construction does not change the global flow in the region.
\end{abstract}

Keywords: Hydrodynamic Model; Velocities Simulation; Section of Belém Shore; Groins.

\section{Applicação de um modelo 2D tipo águas rasas para analisar o escoamento e o uso de espigões para proteger uma área do estuário do rio Amazonas}

\section{RESUMO}

Belém, capital do Pará, passa por um processo de revitalização de sua orla, onde está sendo executado o aterro hidráulico de um trecho da confluência entre o rio Guamá e a baía do Guajará. Nessa área aterrada serão construídos uma avenida de mão dupla e um complexo de lazer e turismo. Para tanto, a proteção da obra pode ser necessária para se minimizar a perda de material durante a execução dos trabalhos e depois para a própria conservação do complexo turístico. Outro ponto importante é a análise do impacto do projeto no escoamento 
global da confluência entre o rio Guamá e a baía do Guajará. Assim, um modelo hidrodinâmico $2 \mathrm{D}$ via método dos elementos finitos é utilizado para simular as velocidades na região em três modelos: o primeiro com a configuração natural da área, o segundo protegido com espigões e o terceiro com o projeto implantado. Os campos de velocidade com e sem a presença da obra servem para caracterizar os impactos sofridos pelo escoamento natural no trecho considerado. A simulação do modelo protegido mostra a eficácia dos espigões em reduzir as velocidades das correntes. De maneira geral, a implantação do projeto não muda o escoamento global da região.

Palavras-chave: Modelo hidrodinâmico; Simulação do escoamento; Trecho da orla de Belém; espigões.

\section{INTRODUCTION}

Estuaries are coastal water bodies connected to the ocean where seawater and fresh water from the continent mix. On the basis of such definition, countless coastal aquatic systems fit in such as bays, lakes and rivers with their own and distinguished geomorphologic and hydrodynamic characteristics that make them unique (Schettini and Carvalho, 1999). Such aquatic systems are subject to periodic flooding and the side shift of the river (receding embankments), which damage the groins. The Amazon River estuary is an aggravating feature of the tide effect, which can vary by up to 4 meters, as is the case of Belém (Barros et al., 2005; Sena and Amarante Mesquita, 2004). In this region, hydraulic constructions must be protected against the effects of sediment load transport, since the sediment load from the Amazon River and Araguaia-Tocantins basin is huge (Figure 1).

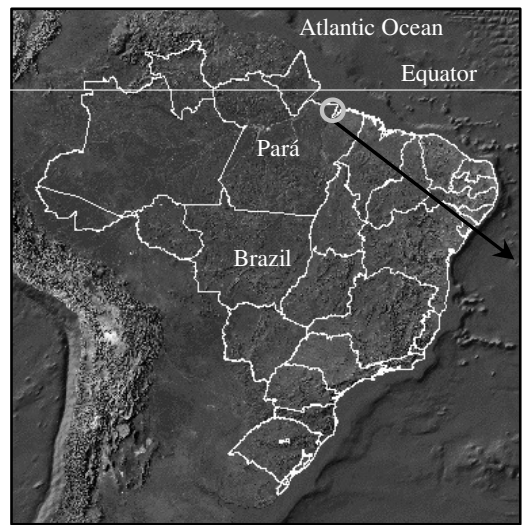

(a)

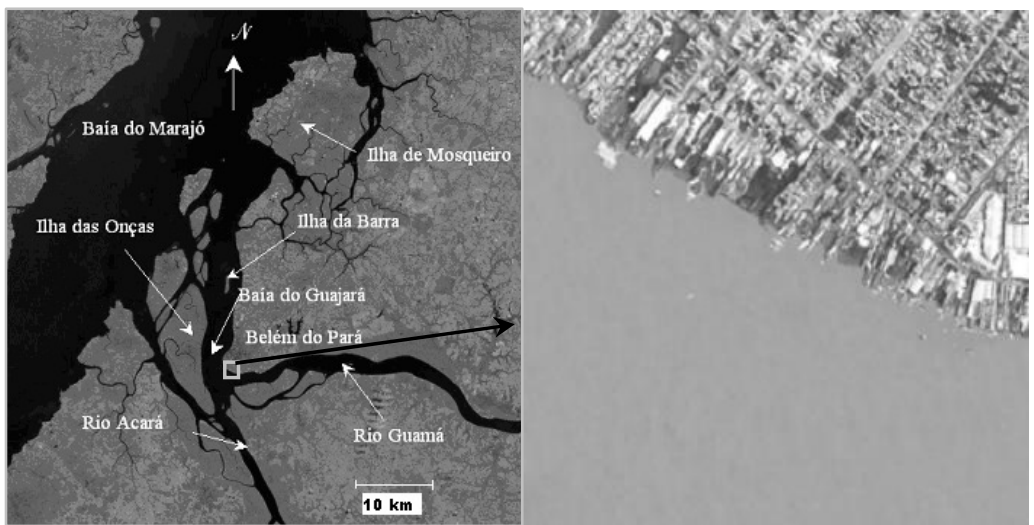

(b) (c)

Figure 1. Brazil (a), Guamá River / Guajará Bay confluence (b), and study area (c).

Belém, the capital of Pará State, is located in the North of Brazil below the Equator at the following coordinates: $01^{\circ} 28^{\prime} 03$ " $\mathrm{S}$ and $48^{\circ} 29^{\prime} 18^{\prime \prime} \mathrm{W}$; and its population is approximately 1.5 million. The waterfront of the city has been under a beautification process, which includes the hydraulic embankment at the confluence of Guamá River and Guajará Bay (Figure 1). A two-way avenue and a leisure and tourist complex will be built on this filled area. Therefore, protection of the construction site may be required in order to minimize loss of material during the work and after to conserve the tourist complex. Beside that, it is important to analyze the impact of the construction on the global flow at the confluence of the Guamá River and the Guajará Bays since nutrients and pollutants transport is a function of water circulation (Martin and McCutcheon, 1999). Above all, the pollutants that circulate in the analyzed region come from the city of Belém. 
The introduction of engineering works in coastal and estuary zones has been the subject of recent studies. For instance, Pawlak and MacCready (2002) examined the oscillatory flow along a coastline zone with a series of headlands and cliffs and demonstrated that the amount of movement can be transferred from the coasts to the inside by means of standard residual flow. This phenomenon is important when erecting such structures as ports, dams, groins, hydraulic embankment etc. The analysis of this kind of flow is complex and many times requires the use of numeric models connected to georeferenced systems. Zhang et al. (2004) and Casulli and Walters (2000) introduced a 3-D model with non-structured mesh. However, many times, using 2D georeferenced models, with structured meshes or not, is enough for velocity and depth simulations of Rivers and estuaries. Examples of 2D model applications can be found in Novikov and Bagtzoglou (2006) and Inoue and Wiseman Jr. (2000).

This paper uses a shallow water 2-dimensional hydrodynamic model (Secretan and Leclerc, 1998). Studies conducted by Sena et al. (2003), Sena and Amarante Mesquista (2004), Barros et al. (2005) and Blanco et al. (2006) corroborate the efficiency of the model for the region of application, thus allowing the flow simulation and the consequent estimate of velocities. The natural configuration models followed by groins are analyzed, which are dedicated to slowing down the flow near the edges of the waterfront in order to protect execution of the works.

The Guajará Bay model was calibrated with field data obtained in September 2004. In the Amazon, September is characterized by low flow as the rains are not regular. The embankment works were to be executed during this period to avoid the regular rains that occur six months later. We could, therefore, reuse the calibration data for the present study. However, to use the model during the rain period, for the Amazon flood, boundary conditions need to be updated.

\section{MATERIAL AND METHODS}

\subsection{The Hydrodynamic Model}

A 2-dimensional horizontal hydrodynamic model is adopted. In this case, the mass conservation and momentum equations are integrated with respect to the depth. Thus, the problem becomes two-dimensional and the values obtained for the velocities are mean values in the vertical direction. These types of models are referred to as Saint-Venant, or shallow waters. The main conditions to be fulfilled for using this model are as follows (Heniche et al., 2000):

- the water column is mixed in the vertical direction and the depth is small in comparison with the width and the length of the water volume;

- the waves are of small amplitude and long period (tide waves). The acceleration's vertical component is negligible, allowing for hydrostatic pressure approximation.

Equations (1) to (3) are the conservative form of the Saint-Venant equations. The first is the continuity equation, whereas the other two are the momentum conservation equations for the fluid, in $\mathrm{x}$ and $\mathrm{y}$ directions, respectively.

$$
\begin{aligned}
& \frac{\partial \mathrm{h}}{\partial \mathrm{t}}+\frac{\partial \mathrm{q}_{\mathrm{x}}}{\partial \mathrm{x}}+\frac{\partial \mathrm{q}_{\mathrm{y}}}{\partial \mathrm{y}}=0 \\
& \frac{\partial \mathrm{q}_{\mathrm{x}}}{\partial \mathrm{t}}+\frac{\partial \mathrm{q}_{\mathrm{x}} \frac{\mathrm{q}_{\mathrm{x}}}{\mathrm{H}}}{\partial \mathrm{x}}+\frac{\partial \mathrm{q}_{\mathrm{x}} \frac{\mathrm{q}_{\mathrm{y}}}{\mathrm{H}}}{\partial \mathrm{y}}=\sum \mathrm{F}_{\mathrm{x}}
\end{aligned}
$$


$\frac{\partial \mathrm{q}_{\mathrm{y}}}{\partial \mathrm{t}}+\frac{\partial \mathrm{q}_{\mathrm{y}} \frac{\mathrm{q}_{\mathrm{x}}}{\mathrm{H}}}{\partial \mathrm{x}}+\frac{\partial \mathrm{q}_{\mathrm{y}} \frac{\mathrm{q}_{\mathrm{y}}}{\mathrm{H}}}{\partial \mathrm{y}}=\sum \mathrm{F}_{\mathrm{y}}$

$\mathrm{q}_{\mathrm{x}}$ are $\mathrm{q}_{\mathrm{y}}$ are the flow rates in the Cartesian coordinates $\mathrm{x}$ e $\mathrm{y}, \mathrm{t}$ is for time, $\mathrm{h}$ is the water level, $\mathrm{H}$ is for the depth of the water column, and $\mathrm{F}_{\mathrm{x}}$ and $\mathrm{F}_{\mathrm{y}}$ are the volume forces in $\mathrm{x}$ and $\mathrm{y}$ directions.

$F_{x}$ and $F_{y}$ are given by equations (4) and (5).

$$
\begin{aligned}
& \sum \mathrm{F}_{\mathrm{x}}=-\mathrm{gH} \frac{\partial \mathrm{h}}{\partial \mathrm{x}}-\frac{\mathrm{n}^{2} \mathrm{~g}|\overrightarrow{\mathrm{q}}| \mathrm{q}_{\mathrm{x}}}{\mathrm{H}^{1 / 3}}+\frac{1}{\rho}\left(\frac{\partial\left(\mathrm{H} \tau_{\mathrm{xx}}\right)}{\partial \mathrm{x}}\right)+\frac{1}{\rho}\left(\frac{\partial\left(\mathrm{H} \tau_{\mathrm{xy}}\right)}{\partial \mathrm{y}}\right)+\mathrm{F}_{\mathrm{cx}}+\mathrm{F}_{\mathrm{wx}} \\
& \sum \mathrm{F}_{\mathrm{y}}=-\mathrm{gH} \frac{\partial \mathrm{h}}{\partial \mathrm{y}}-\frac{\mathrm{n}^{2} \mathrm{~g}|\overrightarrow{\mathrm{q}}| \mathrm{q}_{\mathrm{y}}}{\mathrm{H}^{1 / 3}}+\frac{1}{\rho}\left(\frac{\partial\left(\mathrm{H} \tau_{\mathrm{yx}}\right)}{\partial \mathrm{x}}\right)+\frac{1}{\rho}\left(\frac{\partial\left(\mathrm{H} \tau_{\mathrm{yy}}\right)}{\partial \mathrm{y}}\right)+\mathrm{F}_{\mathrm{cy}}+\mathrm{F}_{\mathrm{wy}}
\end{aligned}
$$

where $g$ is the acceleration of gravity; $n$ is the Manning coefficient; $|\vec{q}|$ is the modulus of the specific flow rate; $\rho$ is the water density; $\tau_{i j}$ is the Reynolds stress tensor;

$$
\tau_{i j}=v\left(\frac{\partial \overline{U_{i}}}{\partial x_{j}}+\frac{\partial \overline{U_{j}}}{\partial x_{i}}\right)
$$

$F_{c x}$ and $F_{c y}$ are the Coriolis forces in $x$ and $y$ directions, respectively; and $F_{w x}$ and $F_{w y}$ are the wind forces, in the $x$ and $y$ directions, respectively.

The influence of the wind was not taken into account and will be studied in a subsequent stage. The Coriolis effect was neglected due to the position of the domain, near the Equator.

Bottom friction is taken into account by a friction law of Manning type. The values for the Manning coefficient were used as calibration parameters with initial values obtained from the substrate composition of the Guajará Bay (Pinheiro, 1987).

The turbulence model is a zero equation model of mixing length $\left(\mathrm{L}_{\mathrm{m}}\right)$ type due to Rodi (1993). Where $\mathrm{L}_{\mathrm{m}}$ is the distance between the wall and a point in the flow from of which the wall itself does not influence more the turbulent. This model assumes a balance between creation and dissipation of energy. In this case, the turbulent viscosity is given by:

$$
v_{t}=L_{m}^{2} \sqrt{2 D_{i j} D_{i j}}
$$

$v_{t}$ is the turbulent viscosity; $D_{i j}$ is the $i j$ components of the deformation tensor, given by:

$$
D_{i j}=\frac{1}{2}\left(\frac{\partial \overline{U_{i}}}{\partial x_{j}}+\frac{\partial \overline{U_{j}}}{\partial x_{i}}\right)
$$

where $\overline{U_{i}}$ is the mean velocity in the $i$ direction. 
To complete the system and impose the prescribed flow conditions, the following boundary conditions were adopted:

- at solid boundaries: an impermeability condition was imposed (slip condition). In other words, no flow occurs through the solid boundaries.

- at liquid boundaries: tide levels were imposed as they were obtained through field measurements in September of 2004.

In this analysis, the Modeleur and Hydrosim software have been used. These were developed at INRS-ETE, a research center of the Université du Québec, Canada (Secretan and Leclerc, 1998; Secretan et al., 2000; Heniche et al., 2000). Modeleur is a combination of a Geographic Information System (G.I.S.) and a powerful Finite Element pre- and postprocessor. It allows for the creation of Numerical Terrain Models (NTM) with information concerning topography, riverbed substrate, wind, ice, and aquatic plants. The Modeleur also enables the division of the analyzed region into partitions. Data sets from the NTM are associated to the partitions. An automatic procedure of data treatment in the interfaces of the partitions is used for mesh generation of finite elements, which will be used in the solver to resolve the 2-D Saint-Venant model with a drying/wetting capability to follow the shoreline evolution. This solver is called Hydrosim. More details can be obtained in Secretan and Leclerc (1998).

\subsection{The Numerical Model}

For the study area (Figure 1(c)) the Numerical Terrain Model (NTM) and the hydrodynamic model of the Guajará Bay, used by Barros et al. (2005), are applied. The model is limited to the north by the Marajó Bay, to the south by the Acará River, to the east by Belém, and to the west by the Onças Island (Figure 1(b)).

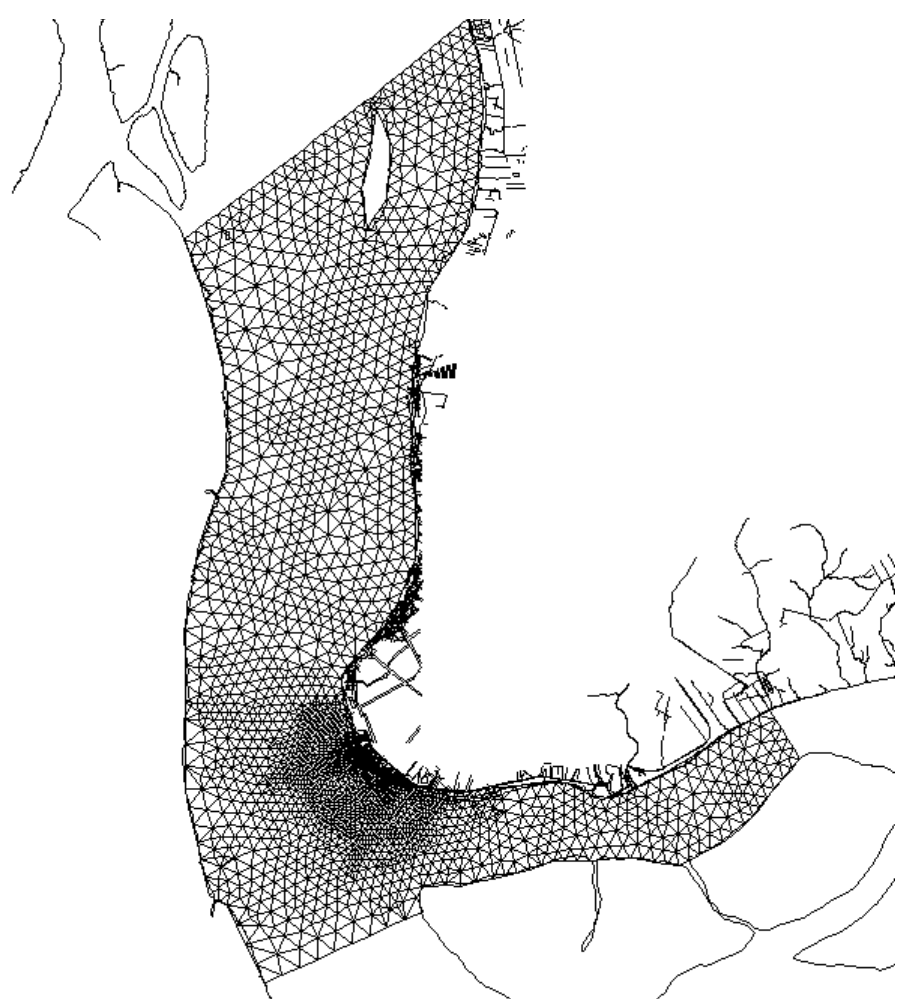

Figure 2. Computer mesh of the model with a refinement in the area of the riverfront project. 
It can be seen that the overall area of the model is much larger than the study area. Thus, a more refined finite elements mesh (Figure 2) is used in the simulations for the present application of the model to the riverfront project. Figure 3 shows the refinement in more details.

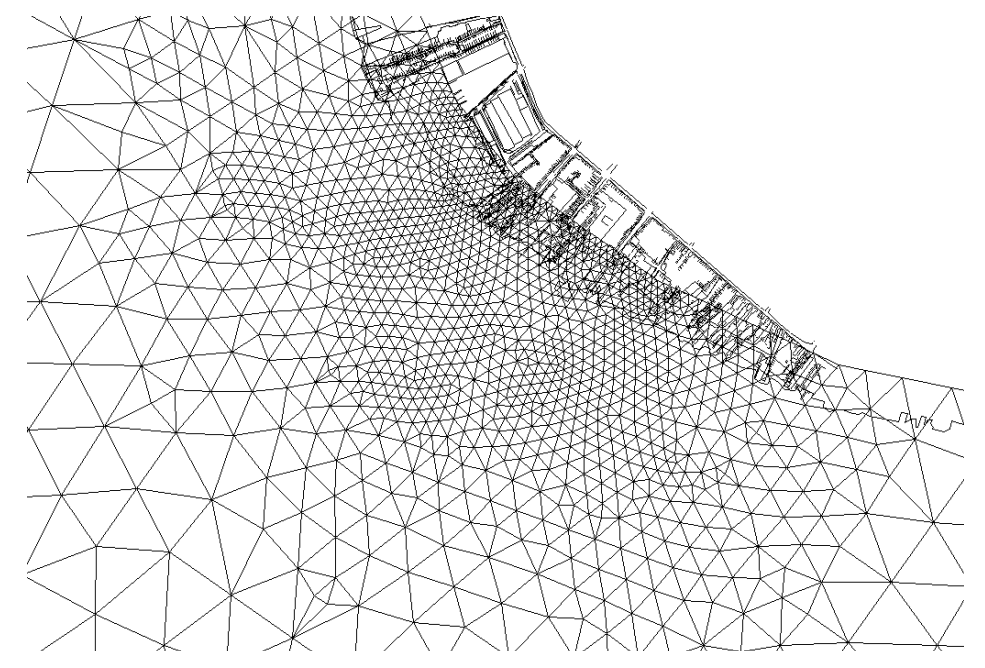

Figure 3. Refinement of the mesh in the Belém Riverfront Project region.

\section{RESULTS AND DISCUSSION}

With an aim at protecting the riverfront, thus preventing loss of material during the hydraulic embankment works, configurations with 50-meter groins were studied (the first with one groin and the second with two groins) and compared to the natural conditions. Moreover, the flow with and without the project was simulated at the confluence of the Guamá River and the Guajará Bay. This simulation was performed to analyze the impacts on the flow of the region.

All simulations were compared on the most critical moment, that is, those with maximum velocity during flood and ebb tides. They are simulated with September 2004 conditions since they reproduce the conditions of operation.

\subsection{Natural Configuration}

The first result of the flow simulation refers to the natural configuration of the study area. Figure 4 shows the flood (Figure 4(a)) and ebb tide (Figure 4(b)) velocities.
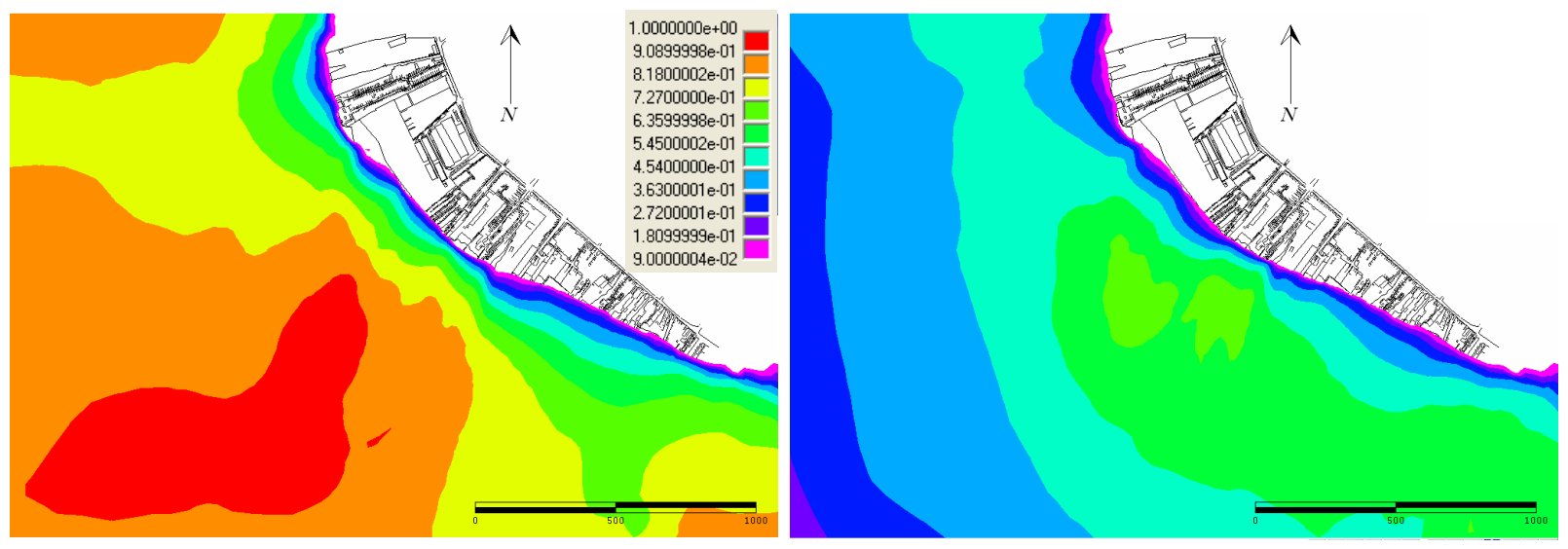

Figure 4. Flood (a) and ebb tide (b) simulated maximum velocity field. 
By analyzing Figure 4, flow tide velocities are observed to be greater than those for ebb tide. This is due to the Guamá River dynamic that drives the flow in front of Ilha das Onças (Onças Island) (Fig. 1(b)) during the ebb tide cycle. On the other hand, the flow is better distributed in the Guajará Bay during the flood tide, increasing the velocities close to the Belém shoreline. This first result demonstrates that the velocities at the banks where the project is to be implemented, both in flow tide and ebb tide, are between 0.09 and $0.55 \mathrm{~m} / \mathrm{s}$.

\subsection{Configuration with one groin}

Figure 5 shows flow velocity fields with one-groin configuration, which is positioned in the north section of the study area.
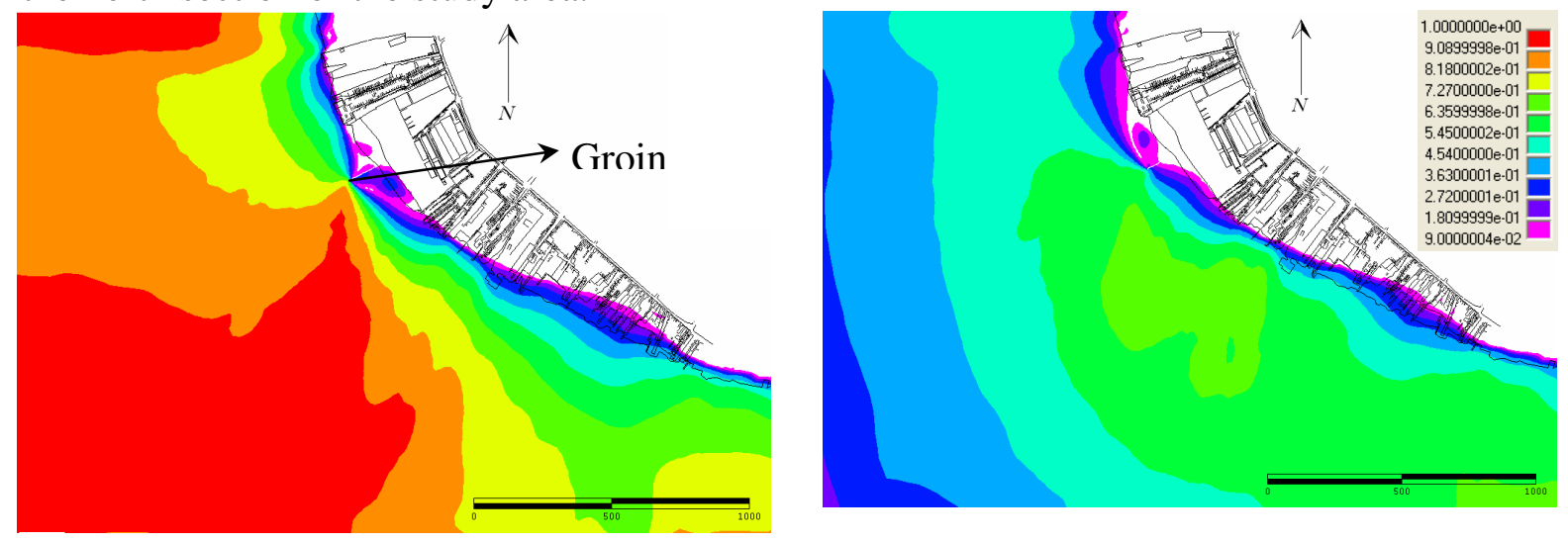

Figure 5. Flood tide (a) and ebb tide (b) maximum velocities with one groin.

Through Figure 5(a), flood tide, it can be noticed that around the groin the velocities on the embankment drop, as expected, not exceeding $0.09 \mathrm{~m} / \mathrm{s}$ at the right face of the groin. As for the left face of the groin, velocities may reach $0.36 \mathrm{~m} / \mathrm{s}$. This figure, however, is confined to a whirlpool zone, which shall not bring about loss of material should the drag velocity be lower than $0.36 \mathrm{~m} / \mathrm{s}$. The same figure shows the velocities concentration in the groin extremity.

By analyzing Figure 5(b), ebb tide flow, it can be noticed that the velocities on the embankment also drop, not exceeding $0.36 \mathrm{~m} / \mathrm{s}$ at the left face of the groin. On the right face, velocities reach $0.27 \mathrm{~m} / \mathrm{s}$; however, this value is confined to a whirlpool zone, which shall not bring about loss of material should the drag velocity be lower than $0.27 \mathrm{~m} / \mathrm{s}$. This effect is similar to that found in Figure 5(a). The differences are the velocity amplitudes and tide flow direction, bringing about changes in the whirlpool position.

\subsection{Configuration with two groins}

In order to provide a bigger and better protection of the riverfront, a configuration with two groins was also analyzed. The second groin is positioned south from the first one. Figures 6(a) and 6(b) show the flow velocity fields with such configuration at flood and ebb tides, respectively. 


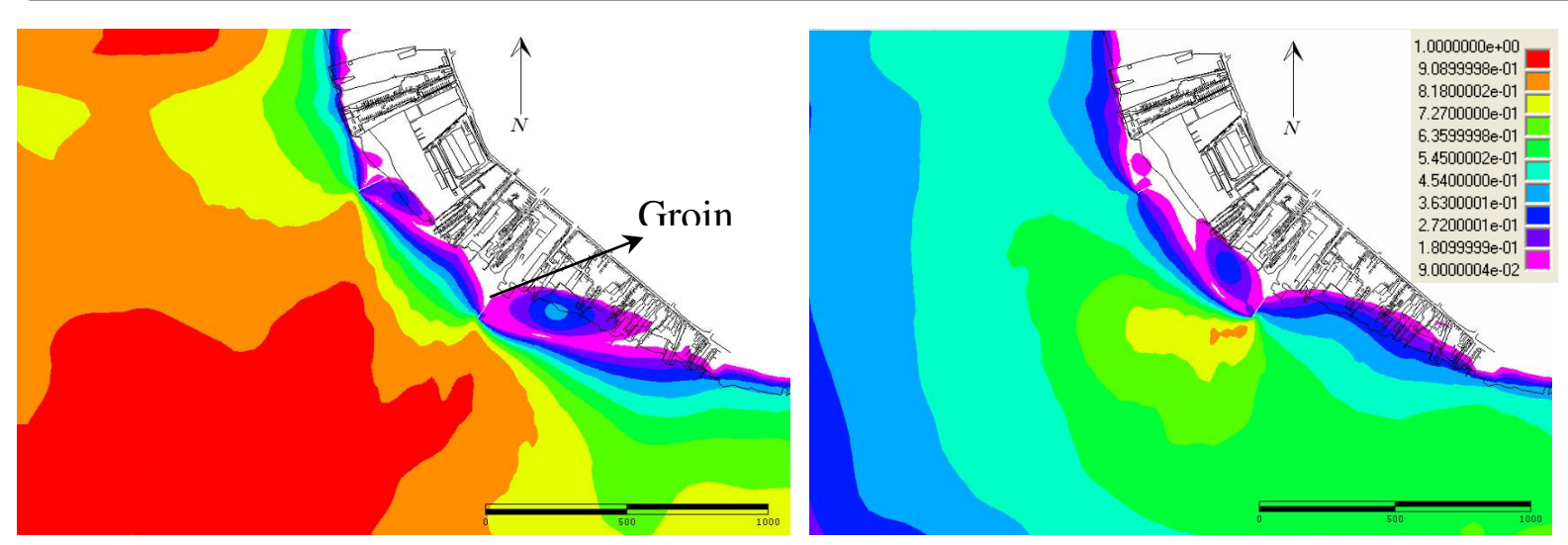

Figure 6. Flood tide (a) and ebb tide (b) maximum velocities with two groins.

By analyzing Figure 6(a), it can be noticed that the flow velocity between the groins does not exceed $0.55 \mathrm{~m} / \mathrm{s}$. This value refers to the region between the edges of the groins, and as one moves toward the embankment, the velocity is reduced to $0.09 \mathrm{~m} / \mathrm{s}$. At the left faces of the groins, recirculation zones are formed, just like it happened in the one-groin configuration. In the recirculation zone behind the first groin, the velocity does not exceed $0.36 \mathrm{~m} / \mathrm{s}$, whereas in the second one it is not higher than $0.45 \mathrm{~m} / \mathrm{s}$.

In Figure 6(b), the velocities between the groins are observed to be lower than those in Figure 6(a). The recirculation zones formed to the left of the groins are now on the right side due to the change in tide direction. It is worth stressing that the velocities in these zones are lower than those recorded for flood tide configuration. In the first groin, the velocity does not exceed $0.18 \mathrm{~m} / \mathrm{s}$ and in the second it is not higher than $0.36 \mathrm{~m} / \mathrm{s}$. It becomes evident that the introduction of the second groin complements the effect of the first, thus deviating stronger currents towards the Guajará Bay. It is also observed that the repulsive effect of the currents in the second groin stretches to the end of the study area, thus assuring that the two-groin configuration is enough to slow the flow velocities down at the Belém Riverfront Project area.

By comparing the figures that characterize the flood tide configurations (Figures 4(a), 5(a) and 6(a)) and ebb tide configurations (Figures 4(b), 5(b) and 6(b)), it can be observed that the more critical scenario, with stronger currents, occurs during flood tide, to the extent that between the two groins during ebb tide (Figure 6(b)) the flow velocity does not exceed 0.36 $\mathrm{m} / \mathrm{s}$, compared to $0.55 \mathrm{~m} / \mathrm{s}$ at flood tide (Figure 6(a)). Thus, the two-groin configuration guarantees a maximum velocity of $0.55 \mathrm{~m} / \mathrm{s}$ on the embankment of the area where the Belém Riverfront Project is to be implemented.

\subsection{The impact of the construction work on the flow at the confluence of the Guamá River and Guajará Bay}

In general, the Belém Riverfront Project has little impact on the flow at the confluence of the Guamá River and Guajará Bay, as can be observed in the velocity fields of Figure 7. This Figure shows the maximum tide velocities at flood tide with and without construction works, since the latter is the most critical situation for the analysis. 


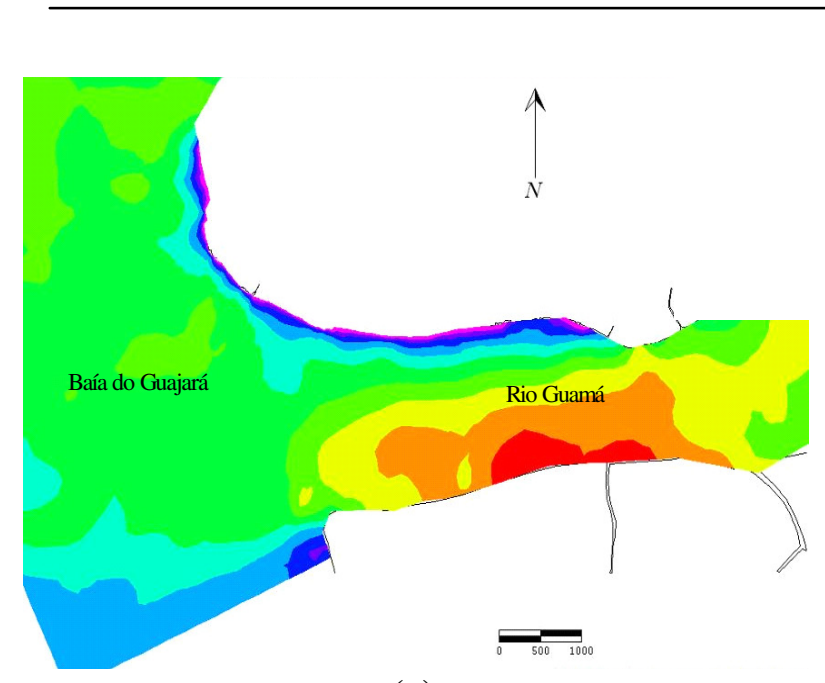

(a)

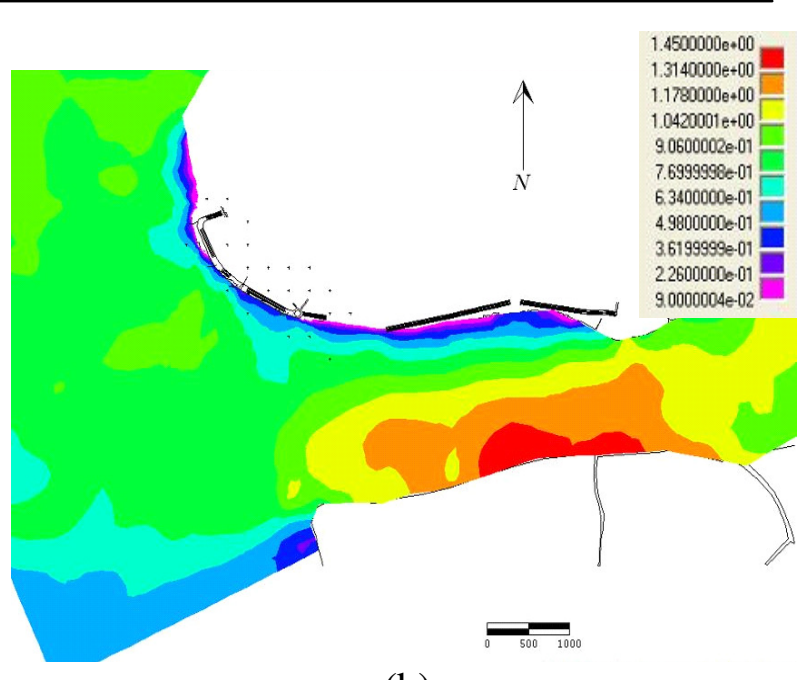

(b)

Figure 7. Overall flow at flood tide without (a) and with (b) the construction works.

\section{CONCLUSIONS}

This study demonstrates the application of a Saint-Venant hydrodynamic model to simulate the effect of groins at the riverfront of Belém city at the estuary of the Amazon River.

Simulated flow configurations in flood tide and ebb tide cycles are compared. At the flood tide cycle, the overall velocities are higher than in the ebb tide cycle at the region of interest. This is explained by the peculiar dynamics of the Guamá River, which concentrates the flow in its main channel during the ebb tide cycle. Such a channel is not located near the region of interest, but on the opposite shore, at Ilha das Onças (Onças Island). At flood tide, on the other hand, the flow is better distributed throughout the width of the Guajara Bay, the velocities increase in the area near the riverfront section object to this study.

Thus, models without groins that represents the natural configuration; and with one or two groins are used to simulate flow velocities at the project area. The configurations including groins serve to protect the filled area. The simulated velocity fields with two-groins configuration push stronger currents towards the Guajará Bay, thus providing better protection for the area to be filled and revitalized. Besides this, the simulated velocities with the three models help to prevent loss of material of the hydraulic embankment project through the comparison of the simulated velocities to the material drag velocities.

As can be observed in the overall flow analysis, the effect of the construction on the flow at the confluence of the Guamá River and Guajará Bay shows no significance. Thus, the circulation of nutrients and pollutants in the region is not affected, since there are no more floodplain areas with vegetation at the site of the construction, but rather households and facilities. Therefore, no significant changes in the distribution of such regions shall occur.

\section{ACKNOWLEDGEMENTS}

The authors wish to thank CNPq - "Conselho Nacional de Desenvolvimento Científico e Tecnológico", of the Brazilian Ministery for Science and Technology, through the dossier n. 550461/01-9 (PNOPG/2002); SECTAM - "Secretaria de Ciência e Tecnologia", of the State of Pará, through the dossier 078/01-SECTAM/FUNTEC/IESAM; and ENGESOLO company; for the financial support provided. 


\section{REFERENCES}

BARRoS, M. L. C.; SENA, M. J. S.; AMARANTE MESQUITA, A. L. Estudo Computacional do Comportamento Hidrodinâmico: Caso da Baía do Guajará. In: SIMPÓSIO BRASILEIRO DE RECURSOS HÍDRICOS, 16., 20-24 nov. 2005, João Pessoa Anais... João Pessoa: ABRH, 2005. 1 CD-ROM.

BLANCO, C. J. C.; SENA, M. J. S.; AMARANTE MESQUITA, A. L. Simulação do escoamento sobre um trecho da orla de Belém-PA para análise de transporte de sedimentos e impactos do projeto orla de Belém. In: ENCONTRO NACIONAL DE ENGENHARIA DE SEDIMENTOS, 7., 20-24 nov. 2006, Porto Alegre Anais... Porto Alegre: ABRH, 2006. 1 CD-ROM.

CASULLI, V.; WALTERS, R. A. An unstructured grid three-dimensional model based on the shallow-water equations. International Journal for Numerical Methods in Fluids, n. 32, p. 331-348, 2000.

HENICHE, M. A.; SECRETAN, Y.; BOUDREAU, P.; LECLERC, M. A two-dimensional finite element drying-wetting shallow water model for rivers and estuaries. Advances in Water Resources, n. 23, p. 359-372, 2000.

INOUE, M. E W. J.; WISEMAN JR., W. J. Transport, mixing and stirring processes in a Louisiana Estuary: a model study. Estuarine, Coastal and Shelf Science, n. 50, p. 449466, 2000.

MARTIN, L.; MCCUTCHEON, S. C. Hydrodynamics and Transport for Water Quality Modeling. Boca Raton: CRC PRESS, 1999. 794 p.

NOVIKOV, A.; BAGTZOGLOU, A. C. Hydrodynamic Model of the Lower Hudson River Estuarine System and its Application for Water Quality Management. Water Resources Management, v. 20, n. 2, p. 257-276, 2006.

PAWLAK, G.; MACCREADY, P. Oscillatory flow across an irregular boundary. Journal Geophysics Research, v. 107, n. C5, p. 4.1- 4.17, 2002.

PINHEIRO, R. V. Estudo hidrodinâmico e sedimentológico do Estuário Guajará - Belém. 1987. 164f. Dissertação (Mestrado em Geoquímica) - Centro de Geociências, Universidade Federal do Pará, Belém, 1987.

RODI, W. Turbulence models and their application in hydraulics: a state of the art review. 3. ed. Balkema: Taylor \& Francis, 1993. 104p.

SCHETTINI, C. A. F.; CARVALHO, J. L. B. Caracterização hidrodinâmica do Estuário do Rio Cubatão, Joinville. Notas Técnicas Facimar, n. 3, p. 87-97, 1999.

SECRETAN, Y. et al. Modeleur: user's guide 1.0a07. Québec: INRS-Eau, 2000. 235p.

SECRETAN, Y.; LECLERC, M. Modeleur: a 2D hydrodynamic GIS and simulation software. In: HYROINFORMATICS-98, 24-26 Aug. 1998, Copenhagen. Proceedings.... Copenhagen: Balkema, 1998. p. 1-18.

SENA, M. J. S.; AMARANTE MESQUITA, A. L. Descrição da técnica de modelagem numérica do escoamento na Baía do Guajará. In: UHLY, S.; SOUZA, E. (Eds.). A Questão da água na Grande Belém. Belém: Fundação Heinrich Böll, 2004. p. 207230 . 
BLANCO, C. J. C.; MESQUITA, A. L. A.; SENA, M. J. S.; SECRETAN, Y. Application of a 2D shallow water model to analyze the flow and the use of groins to protect an area of the Amazon river estuary. Ambi-Agua, Taubaté, v. 4, n. 2, p. 10-20, 2009. (doi:10.4136/ambi-agua.82)

SENA, M. J. S; AMARANTE MESQUITA, A. L.; CRUZ, D. O. A.; SECRETAN, Y. Modelagem das características globais do escoamento na Baía do Guajará. Revista do IESAM, n. 1, p. 105-118, 2003.

ZHANG, Y.; BAPTISTA, A. M.; MYERS III, E. P. A cross-scale model for 3D baroclinic circulation in estuary-plume-shelf-systems: part I. Formulation and skill assessment. Continental Shelf Research, v. 24, n. 18, p. 2187-2214, 2004. 